\title{
Synthesis characterization and adsorption study of new resin PVC8-hydroxyquinoline-5-sulfonic acid with toxic metals
}

\author{
Mahmoud Najim A. Al-Jibouri, Taghreed M. Musa, Mudeer Mubarak, Wessal M. al-Jibouri \\ Chemistry Department, college of Science, Al-Mustansiryah, Iraq \\ Email address: \\ mahmoudnajim71@yahoo.com(M. N.A. Al-Jibouri), taghreedmohya@yahoo.com(T. M. Musa), mudeersm@yahoo.com(M. Mubarak), \\ wessalmetab@yahoo.com(W. M. al-Jibouri)
}

To cite this article:

Mahmoud Najim A. Al-Jibouri, Taghreed M. Musa, Mudeer Mubarak, Wessal M. al-Jibouri. Synthesis Characterization and Adsorption Study of New Resin PVC8-Hydroxyquinoline -5-Sulfonic Acid with Toxic Metals. Science Journal of Chemistry.

Vol. 1, No. 4, 2013, pp. 38-49. doi: 10.11648/j.sjc.20130104.11

\begin{abstract}
A new chelating copolymer (8HQ-pvc) was prepared through condensation reaction of 8-hydroxyquinoline -5-sulphonic acid with poly (vinyl chloride) in the presence of pyridine as catalyst. This newly developed resin (8-HQ-pvc) has been used to prepare a series of six polymeric chelates by using $\mathrm{Cr}(\mathrm{III}), \mathrm{Co}(\mathrm{II}), \mathrm{Ni}(\mathrm{II}), \mathrm{Cu}$ (II), $\mathrm{Cd}$ (II), $\mathrm{Hg}$ (II) and $\mathrm{Pb}$ (II) ions. Both the parent chelating resin and its metal chelates have been systematically investigated in detail to elucidate the chemical structure by micro elemental analysis and spectral methods(IR, ${ }^{1} \mathrm{H}-{ }^{13} \mathrm{C}$ NMR, and Uv-Vis) spectra, as well as the isometric studies to deduce the average molecular weights of repeated unit in polymeric metal complexes.. In addition to these magnetic susceptibility measurements of the solid metal complexes of PVC-8HQ and the molar conductance of thier solutions in DMSO solutions have been measured to investigate the stereo chemical structures. The chemical structure of metal chelates on the basis of elemental and IR data suggests that the bi dentate (8HQ-pvc) resin coordinate to metal ions through oxygen atom of SO3-H group by replacing $\mathrm{H}$ atom and nitrogen of the quinolone ring. Ion exchange properties of the newly resin were studied for $\mathrm{Cr}^{3+}, \mathrm{Co}^{2+}, \mathrm{Ni}^{2+}, \mathrm{Cu}^{2+}, \mathrm{Pb}^{2+}$ and $\mathrm{Hg}^{2+}$ ions in aqueous solutions. Batch equilibrium method was employed over wide PH range and interval times and showed that PVC-8HQ resin showed a higher selectivity toward $\mathrm{Cr}^{3+}$, $\mathrm{Cu}^{2+}$ and $\mathrm{Cd}^{2+}$ ions.
\end{abstract}

Keywords: PVC, Chelating Properties of Resin and 8-Hydroxyquinoline

\section{Introduction}

Selective chelation of specific metal ions to bring specific properties to the modified material, such as enhanced thermal stability, multiphase physical responses, compatibility, impact response, flexibility, and rigidity is a field of active research ${ }^{(1)}$. A number of ligands including polydentate amines, crown ethers, phosphates and bipyridines have been bound with mainly poly(styrene-divinylbenzene)copolymers ${ }^{(2)}$.

These studies are mostly concerned with ion-binding and catalytic aspects. Very little Synthesis of polymer-bound chelating ligands and the information appears to exist as to whether, and to what extent, such organic compounds can influence the properties of the macromolecule ${ }^{(3)}$. Recently, scientists were able to modify PVC, one of the most versatile plastics, by introduction aromatic and heterocyclic moieties through halogen displacement reaction . PVC, thus modified, showed improved overall photochemical stability and optical properties ${ }^{(4)}$. A number of ligands including polydentate amines, crown ethers, phosphine and bipyridines have been bound with mainly poly (styrene-divinylbenzene) $^{(5)}$. The facial chlorine displacement from PVC indicated the possibility on easy anchoring of ligands to PVC matrix and the subsequent synthesis of immobilized transition metal complexes ${ }^{(6)}$. This article will describe the modification of PVC with anchoring ligand and study its optical properties.

Contamination of water resources by heavy metals has been serious environmental worldwide problem. Heavy metal pollution exists in waster effluents of many industries such as metal plating facilities .fertilizer industry, mining operations tanners, paints and pigments. Heavy metals are not biodegradable and tend to accumulate in living organisms, causing various diseases and disorders ${ }^{(7)}$. It is 
also known that heavy metals are carcinogenic. Therefore it is necessary to treat such toxic metals containing wastewater before discharging ${ }^{(8)}$.Among the conventional methods to remove heavy metals from wastewater include chemical precipitation, ion -exchange, membrane filtration, the adsorption has attracts attention as the results of new material type, available for the application of heavy metal removals. The adsorption involving chelation of metal ions to functional groups of adsorbent is avery efficient way to in activate and remove metal ions and chelating resins characterization by functional groups containing O,N and / or $\mathrm{S}$ and $\mathrm{P}$ donor atoms coordinate to different metal ions ${ }^{(9,10)}$ have been widely studied mostly by experimental methods modification of polymers such as polymehylmetha acylate polystyrene, PVC with derivative having heterocyclic ring or functional groups (isomethine $\mathrm{C}=\mathrm{N}$, hydroxyl groups $-\mathrm{OH}-$ and others.) will be helpful to act as chelating resin for toxic metals ${ }^{(12,13)}$.R. N Singruand co-worker ${ }^{(14)}$ have been established new resin modified from poly(vinyl chloride) with 1,3,5-Tris(8-quinolin ox methyl)-2,4-6-trimethylbenzene, as ion selective electrode.

The present paper explored the newly eco-friendly synthesized polymer resin-pvc8-hydroxy-quinoline-5-sulphonic acid (PVC-8HQ) in the light of its chelating properties on the basis batch equilibrium method towards pb(II), $\mathrm{Cd}(\mathrm{II}), \mathrm{Hg}(\mathrm{II}), \mathrm{Ni}(\mathrm{II})$, $\mathrm{Cr}(\mathrm{III})$ and $\mathrm{Cu}(\mathrm{II})$ ions.

\section{Experimental}

The chemical8-hydroxyquinoline -5-sulphonic acid and purified PVC by tetra hydro furan(T.H.F.) and absolute ethanol are AR grade and chemically pure which is purchased from Fluka .Solvents like dry THF ,Ethanol, $N, N$. dimethylform amide were used with out distillation. 8-Hydroxy quinoline -5-sulphonic acid (0.04mole, 8.44gm) was suspended in dry $\operatorname{THF}(50 \mathrm{Ml}$.) was added to ( $0.5 \mathrm{gm}, 0.04 \mathrm{~mole})$ of poly(vinyl chloride), and three drops of pyridine in $(25 \mathrm{ml}) \mathrm{THF}$. The mixture was refluxed for about $6 \mathrm{hrs}$. until pale yellow precipitate of new resin formed, then filtered and washed with T.H.F and finally ethanol to afford $80 \%$ yield of the resin, scheme (1),

The physical data of the prepared PVC-complexes are found in Table (1).
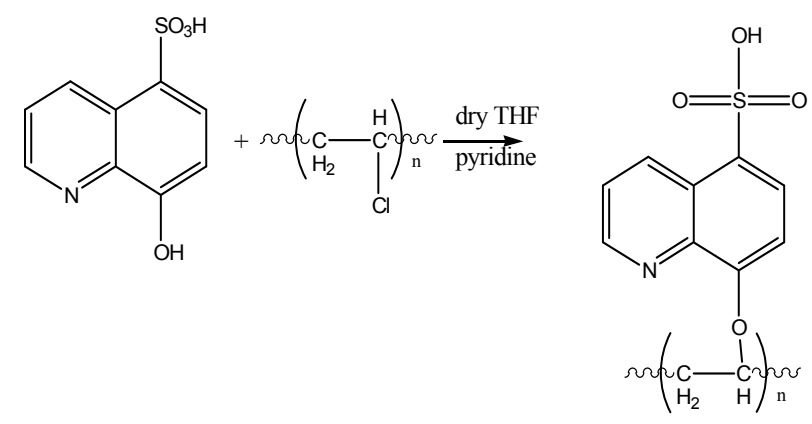

Scheme (1). Synthesis of p.v.c-8HQ-resin

\section{Synthesis of PVC Ligand Complex}

A general procedure can be adopted for the preparation of all the metal complexes as follows : PVC-L-MII complexes were obtained by dissolving 0.5 mole of the appropriate transition metal salt in ethanol and dissolving 1.5 mole of PVC-L dissolved in THF, colored precipitates were obtained then the precipitate was filtered, washed with excess of absolute ethanol. Scheme (1) shows reactions for the synthesis of PVC-L-MII polymer ${ }^{(15)}$.

\section{Characterization of Modification Co Polymers and their Metal Complexes}

Electronic absorption of spectrum of resin in DMSO (spectroscopic grade) and metal chalets solutions were recorded on Shimadzu double beam spectrophotometer in the range of $200-800 \mathrm{~nm}$. Infra-red spectra of $8 \mathrm{H}$ Q-PVC resin and its metal chalets were recordedon Shimadzu160pc spectrophotometer F.T.IR on $\mathrm{KBr}$ and CsI. Pellet, region of $4000-400 \mathrm{~cm}^{-1}$. Nuclear magnetic Resonance (NMR) spectra of newly synthesized resin (PVC-8HQ) have been scanned on Burker Advanced 400NMR spectrometer using $\mathrm{CDCl}_{3}$ at Al-bait University ,Jordon.

\section{Ion-Exchange Properties}

The ion exchange properties of the $8 \mathrm{H}-\mathrm{Q}-\mathrm{PV}$ resin have determined by the batch equilibrium method ${ }^{(16)}$. 8-Hydroxy qunioline -PVC was prepared and transformed to suitable grains after motorized. ${ }^{(17)}$.

\section{Adsorption Experiments}

Batch adsorption experiments were conducted in $100 \mathrm{ml}$ flasks, each of which contained(250-1500)ppm of metal solution prepared with, $\mathrm{Cd}(\mathrm{NO} 3) .4 \mathrm{H} 2 \mathrm{O}, \mathrm{Cr}(\mathrm{NO} 3) 3.9 \mathrm{H} 2 \mathrm{O}$ and $\mathrm{Cu}(\mathrm{NO} 3) 2.2 \mathrm{H} 2 \mathrm{O}$. A0.25gm amount of 8HQ-PVC resin was added in to a flask, containing all contents shaken in a thermostatic water-bath shaker operated at $25 \mathrm{C} 0$ and120rpm and 90min shaking(BS-11 digital, JEIO TECH, Korea, (20-185) rpm , (-10_120 $\left.{ }^{\circ} \mathrm{C}\right) \pm 0.5{ }^{\circ} \mathrm{C}$. Samples were taken from the flask at appropriate time intervals as necessary and the concentration of metal ions in the sample were analyzed with Uv-visible spectroscopy, at maximum absorption $(\lambda$ max nm) table(4). After an experiment, the resin was separated from solution by filtration,

\section{Effect of PH on Metal Ion Exchange Capacity}

To study the effect of $\mathrm{pH}$ onthe metal ion up take, it is necessary to buffer the resin and the solution used. To do this, buffer soluble of $\mathrm{PH}$ range 2-10 were prepared from $0.15 \mathrm{M}$ phosphoric acid and $0.15 \mathrm{M}$ sodium phosphate ${ }^{(18)}$. A pH 
meter (HANA, HI 8417, Fugle) was used to measure the PH.A different sets of weight $(0.25 \pm 0.001 \mathrm{~g})$ dry resin were equilibrated with buffer in differed stopped bottle for $24 \mathrm{hrs}$., so that resin attained desired $\mathrm{pH}$ value ${ }^{(19-20)}$.

\section{Results and Discussion}

The analytical data (C.H.N.M) show the proposed formulas for metal chelate of PVC8HQ- as shown in table (1). All the solid metal chelates of PVC-8HQwith $\mathrm{Cr}^{\text {III }}, \mathrm{Ni}^{\mathrm{II}}$, $\mathrm{Cu}^{\mathrm{II}}, \mathrm{Pb}^{\mathrm{II}}, \mathrm{Cd}^{\mathrm{II}}$ and $\mathrm{Hg}^{\mathrm{II}}$ were soluble in DMF and DMSO .
The measurements of molar conductance ( n 30-45 S.cm ${ }^{2}$

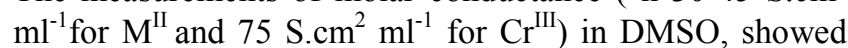
that these chelates are non-electrolytic, except $\mathrm{Cr}^{\mathrm{III}}(8 \mathrm{HQ})$ which showed electrolytic behavior, of in $1: 1$ ratio ${ }^{(21)}$.

The magnetic moments of CrIII) (3.5 BM) revealed the present of three unpaired electrons which agree with octahedral environments around $\mathrm{Cr}^{\mathrm{III}}$ ion , as well as the magnetic moment of $\mathrm{Cu}^{\mathrm{II}}$, chelate ${ }^{(22)}$. As well as the orange Ni(II) complex showed diamagnetic properties, which confirms the square planner geometry around(II )ion ${ }^{(23)}$.

Table (1). Elemental analysis data of 8-HQ-pvc

\begin{tabular}{|c|c|c|c|c|c|c|c|c|}
\hline Compound & $\begin{array}{l}\text { Expected } \\
\text { formula }\end{array}$ & $\begin{array}{l}\text { Molecule } \\
\text { weight }\end{array}$ & $\begin{array}{l}\mathrm{C} \% \\
\text { Calc. } \\
\text { (Found). }\end{array}$ & $\begin{array}{l}\text { \%H } \\
\text { Calc. } \\
\text { (Found.) }\end{array}$ & $\begin{array}{l}\% \mathrm{~N} \\
\text { Calc. } \\
\text { (Found) }\end{array}$ & $\begin{array}{l}\% \mathrm{~S} \\
\text { Calc. } \\
\text { (Found }\end{array}$ & $\begin{array}{l}\text { Intrinsic } \\
\text { viscosity } \\
\eta\end{array}$ & Metal\% \\
\hline PVC-8HQ. & $\mathrm{C}_{13} \mathrm{H}_{15} \mathrm{NO}_{4} \mathrm{~S}$ & 281 & $\begin{array}{l}55.50 \\
(55.31)\end{array}$ & $\begin{array}{l}5.37 \\
(4.81)\end{array}$ & $\begin{array}{l}4.98 \\
(5.71)\end{array}$ & $\begin{array}{l}11.40 \\
(10.02)\end{array}$ & & - \\
\hline Cr-PVC-HQ & $\mathrm{C}_{29} \mathrm{H}_{45} \mathrm{ClCr}_{2} \mathrm{~N}_{2} \mathrm{O}_{12} \mathrm{~S}_{2}$ & 817 & $\begin{array}{l}42.62 \\
(41.31)\end{array}$ & $\begin{array}{l}5.55 \\
(3.11)\end{array}$ & $\begin{array}{l}5.24 \\
(5.33)\end{array}$ & $\begin{array}{l}7.85 \\
(7.04)\end{array}$ & 0.63 & $\begin{array}{l}12.72 \\
(11.12)\end{array}$ \\
\hline Ni-PVC-HQ & $\mathrm{C}_{29} \mathrm{H}_{37} \mathrm{ClNi}_{2} \mathrm{~N}_{2} \mathrm{O}_{8} \mathrm{~S}_{2}$ & 759 & $\begin{array}{l}45.92 \\
(4.34)\end{array}$ & $\begin{array}{l}4.92 \\
(4.03)\end{array}$ & $\begin{array}{l}3.69 \\
(3.33)\end{array}$ & $\begin{array}{l}8.45 \\
(8.01)\end{array}$ & - & $\begin{array}{l}15.47 \\
(14.45)\end{array}$ \\
\hline Cu-PVC-HQ & $\mathrm{C}_{29} \mathrm{H}_{45} \mathrm{ClCu}_{2} \mathrm{~N}_{2} \mathrm{O}_{12} \mathrm{~S}_{2}$ & 840 & $\begin{array}{l}41.45 \\
(42.33)\end{array}$ & $\begin{array}{l}5.40 \\
(4.61)\end{array}$ & $\begin{array}{l}3.33 \\
(3.59)\end{array}$ & $\begin{array}{l}7.63 \\
(6.56)\end{array}$ & 0.69 & $\begin{array}{l}15.12 \\
(14.01)\end{array}$ \\
\hline Cd-PVC-HQ & $\mathrm{C}_{29} \mathrm{H}_{37} \mathrm{ClCd}_{2} \mathrm{~N}_{2} \mathrm{O}_{8} \mathrm{~S}_{2}$ & 866 & $\begin{array}{l}40.22 \\
(38.01)\end{array}$ & $\begin{array}{l}4.31 \\
(4.88)\end{array}$ & $\begin{array}{l}3.33 \\
(3.41)\end{array}$ & $\begin{array}{l}7.41 \\
(7.01)\end{array}$ & 0.72 & $\begin{array}{l}25.96 \\
(24.23)\end{array}$ \\
\hline Hg-PVC-HQ. & $\mathrm{C}_{29} \mathrm{H}_{37} \mathrm{ClHg}_{2} \mathrm{~N}_{2} \mathrm{O}_{8} \mathrm{~S}_{2}$ & 1042 & $\begin{array}{l}33.41 \\
(32.01)\end{array}$ & $\begin{array}{l}3.58 \\
(2.98)\end{array}$ & $\begin{array}{l}2.69 \\
(2.71)\end{array}$ & $\begin{array}{l}6.15 \\
(5.79)\end{array}$ & - & $\begin{array}{l}38.49 \\
(36.98)\end{array}$ \\
\hline
\end{tabular}

$\mathrm{A}=$ average molecular weight of repeated unit in $\mathrm{g} / \mathrm{mol}$.

Table (2). HNMR and $13 H N M R$ spectra of $8 H Q-P p v c-r e s i n$

\begin{tabular}{llr}
\hline Expected chemical shift $(\mathbf{p p m})$ & Nature of proton assigned & Observed chemical shift (ppm) \\
\hline $3.00-3.5$ & $\mathrm{CH}_{2}-\mathrm{CH}$. & $3-3.3$ (multiple) \\
$7.5-8.5$ & Aromatic proton $(\mathrm{Ar}-)$ & No signal \\
$9-10$ & Proton of phenolic-OH- & 9.20 \\
$9.0-10.0$ & Proton of $\mathrm{SO}_{3} \mathrm{H}$ & $9.5($ singlet $)$ \\
\hline
\end{tabular}

\section{1. ${ }^{1} \mathrm{HNMR}$ and ${ }^{13} \mathrm{CNMR}$}

The NMR spectra of PVC-8HQ resin in $\mathrm{CDCl}_{3}$ solvent revealed that the copolymer gave different pattern of ${ }^{1}$ HNMR spectra, table2, since it possesses set of proton having different electronic environment. The chemical shift (ppm) observed at (7.4-8.20) ppm is assigned to de shielding protons of aromatic ring. The signal in the $9.5 \mathrm{ppm}$ region may be due to proton of $-\mathrm{SO}_{3} \mathrm{H}$ group confirming displacement reaction of P.V.C with 8-hydroxyquinoline-5-sulphonic acid via attacking - $\mathrm{OH}$ group of high basicity on carbon bearing chlorine atom of poly(vinyl chloride),Scheme 1.. The much down field chemical shift for $\mathrm{SO}_{3} \mathrm{H}$ indicate clearly the intermolecular hydrogen bonding with adjacent groups in the same copolymer $^{(24)}$. However, the absence of signals of protons of -OH group (8-position) in the new copolymer indicates the substitution reaction of PVC via departure of hydrogen chloride gas in assistance of $-\mathrm{OH}$ group, Figure (1). ${ }^{13} \mathrm{CNMR}$ spectra of new resin display signals arising from all the carbon atoms and hence provide direct information about the carbon skeleton. The ${ }^{13} \mathrm{CNMR}$ spectrum of 8 HQ-PVC resin is shown in figure (2), and the peak positions are assigned according to the literature ${ }^{(25)}$.The absorptions at $160,153,159,172,142,136,148,125$ and $119 \mathrm{ppm}$ with respect to $\mathrm{C}_{1}$ to $\mathrm{C}_{9}$ of the aromatic quinolone ring ${ }^{(26)}$, while absorptions at 40 and $60 \mathrm{ppm}$ may be assigned to $-\mathrm{CH}_{2}$ and $\mathrm{CH}$ - of vinyl group linked to quinolone ring in position 8viahydroxylgroup.Table. (2) 


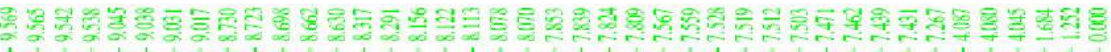

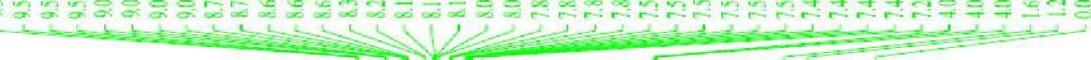

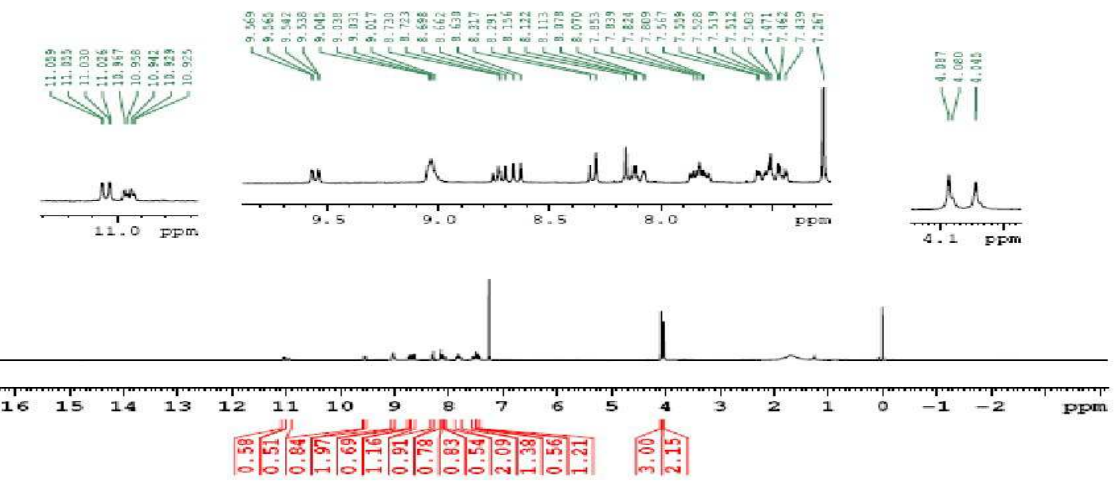

Figure (1). 1H NMR spectra of $8 H Q-p v c$ resin in CDCl 3.

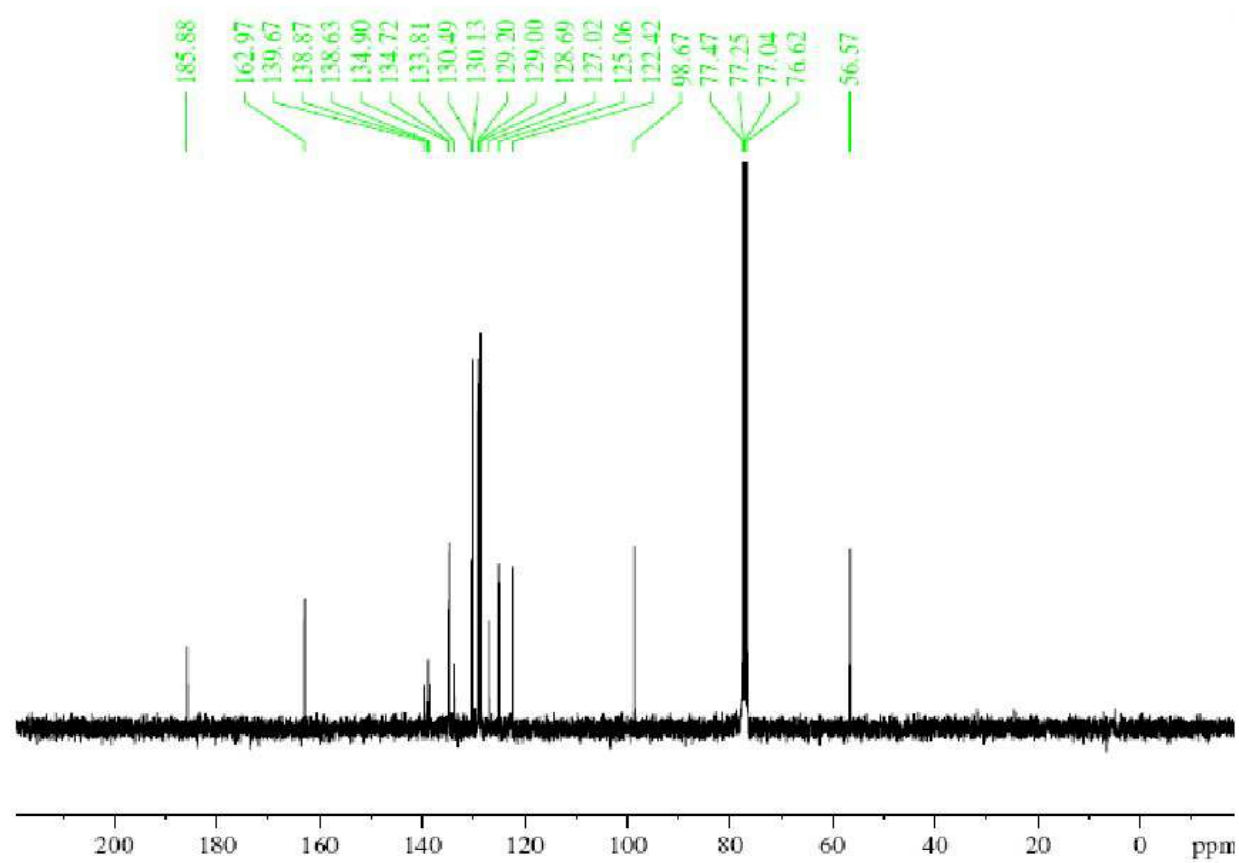

Figure (2). 13 C NMR spectra of $8 H Q-p v c$ resin in $C D C l 3$.

\subsection{IR Spectra}

The FTIR spectrum of (8HQ-PVC)resin, with its metal chelates are presented in figures (3and 4 ).The IR spectrum of PVC-8HQ resin showed broad band appeared in the region $3676 \mathrm{~cm}^{-1}$ may be assigned to the stretching vibration of the intermolecular hydrogen bonded phenol $-\mathrm{SO}_{3} \mathrm{H}$ group. The presence of strong band at $1687 \mathrm{~cm}^{-1}$ and $1602 \mathrm{~cm}^{-1}$ indicate the $\mathrm{C}=\mathrm{N}$ and $\mathrm{C}=\mathrm{C}$ group in quinolone ring ${ }^{(26)}$, which up on complexation, the absorption of $\mathrm{SO}_{3}-\mathrm{H}$ group was disappeared in the infrared of all metal chelates ,this confirms the coordination of PVC-8HQ resin with metal ion through deprotonation depending on the high acidity of sulfonyl groups attached directly to phenyl moieties ${ }^{(27)}$. The depression in the wave numbers of $(\mathrm{C}=\mathrm{N})$ may be explained on the basis of drift of lone pair density of azomethine nitrogen ring toward metal ion ${ }^{(28)}$. The IR spectra of the all complexes showed new bands in the far IR (430-549) $\mathrm{cm}^{-1}$ and 456-530 corresponding to $v(\mathrm{M}-\mathrm{O}$ ) and $v(\mathrm{M}-\mathrm{N})$ vibrations. Furthermore, the far-infrared spectra of all polymeric metal complexes showed weak bands in the $300-385 \mathrm{~cm}^{-1}$ that are assigned to $\mathrm{M}-\mathrm{Cl}$ bonds ${ }^{(29)}$, and hence investigates the participation of $\mathrm{Cl}^{-1}$ ion in completion the coordination numbers of central metal ions, scheme $2^{(30)}$.Furthermore, the strong absorptions at $1426 \mathrm{~cm}^{-1}$ and $1456 \mathrm{~cm}^{-1}$ are attributed to methylene $\mathrm{CH}_{2}-\mathrm{CH}_{2}$ bridge of P.V.C. bonded directly with quinoline ring ${ }^{(31)}$ confirming substitution reaction with hydroxyl group in position(8) of hydroxyl -5-sulphonic acid-quinolone ${ }^{(32)}$. 


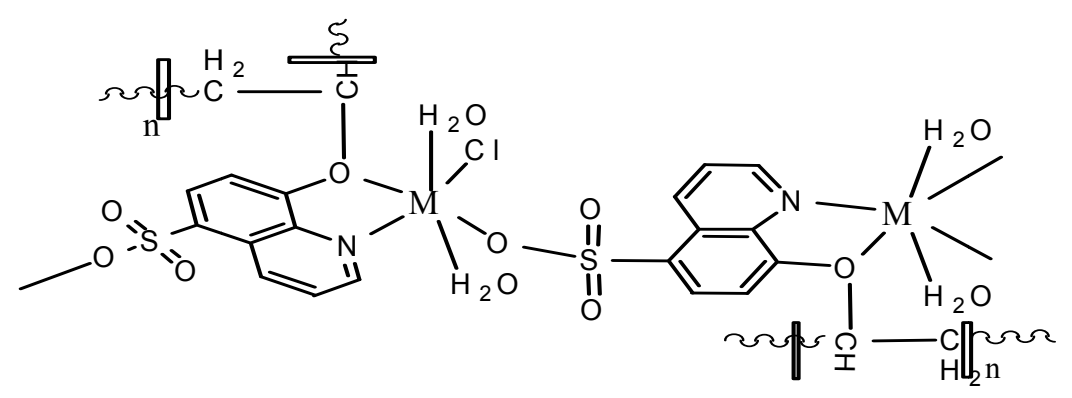

$\mathrm{M}=\mathrm{C}$ rIII, $\mathrm{Cu} \mathrm{II}$

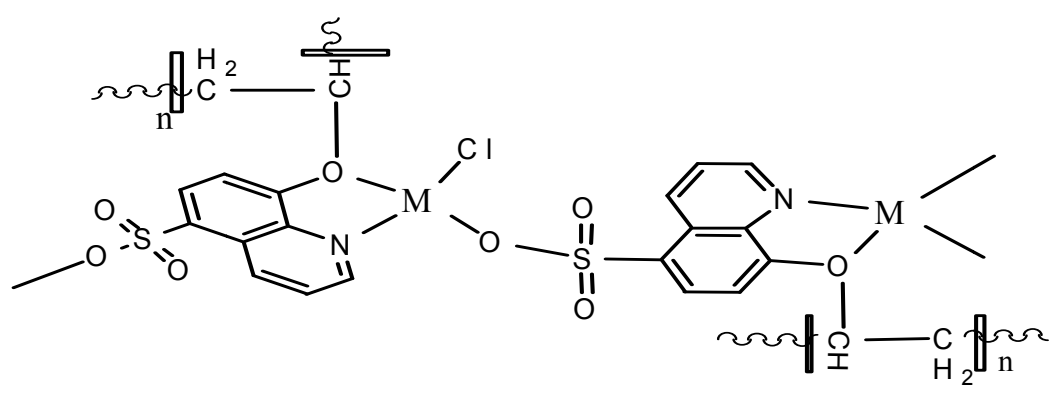

$\mathrm{M}=\mathrm{C}$ o II, N iII, C d II, H g II, P b II

Scheme (2). Coordination patterns of PVC-8HQ Resin with metal ions

由 SHIMADZU

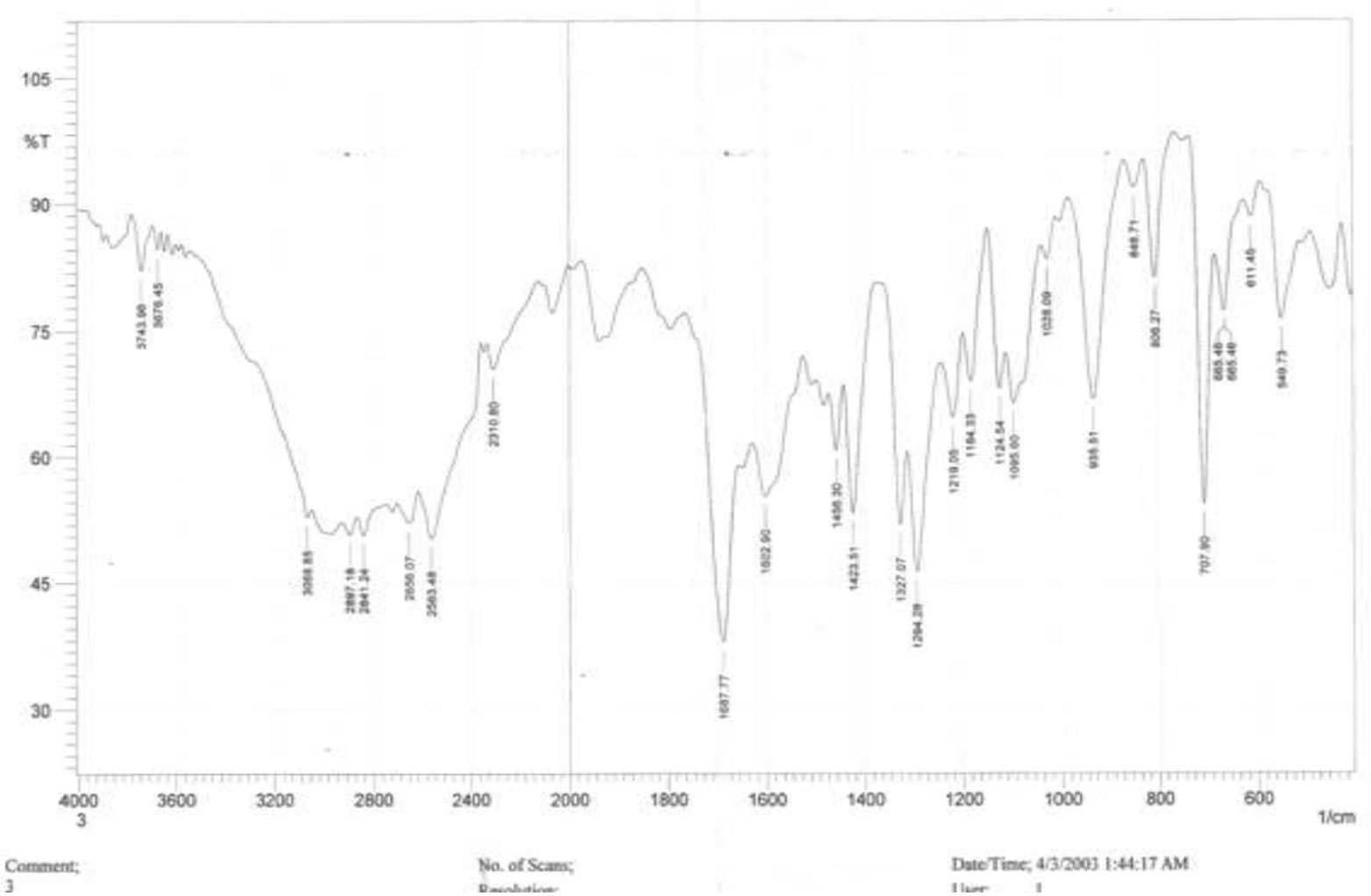

Figure (3). Infrared spectrum of $P V C-8 H Q$ resinin $\mathrm{KBr}$ disc. 


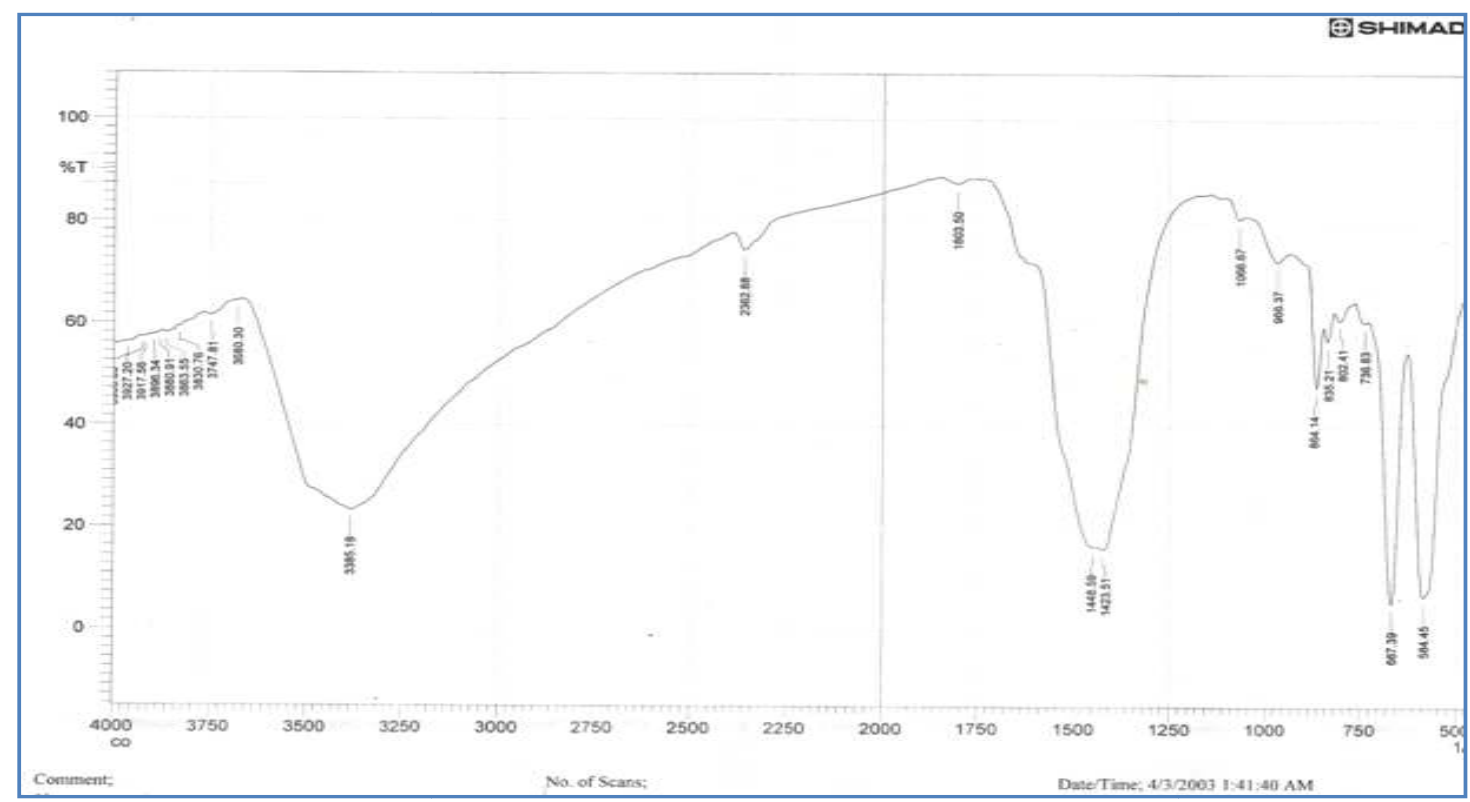

Figure (4). Infrared spectrum of $C u(I I)-P V C-Q$-chelatein $C S I$ disc.

\subsection{UV-Visible Spectra}

The electronic spectra of PVC-8HQ in DMSO solution, Table.(3) showed distinct peaks at $225 \mathrm{~nm}$ and $336 \mathrm{~nm}$ are assigned to $\pi-\pi^{*}$ and $n-\pi^{*}$ transition of chromophoric groups of $\mathrm{S}=\mathrm{O}, \mathrm{C}=\mathrm{N}$ and $\mathrm{C}=\mathrm{C}^{(33)}$. The absorption spectra of copper (II) chelate exhibited bands at $365 \mathrm{~nm}$ and $550 \mathrm{~nm}$ assuming tetragonal distortion in the molecule, since the broadening in the region 550may be assigned to overlapping of two transitions $\mathrm{B}_{1} \mathrm{~g}^{2} \rightarrow \mathrm{B}_{2} \mathrm{~g}^{2}$ and $\mathrm{B}_{2} \mathrm{~g}^{2} \rightarrow \mathrm{Eg}^{2}$,respectively ${ }^{(34)}$. The green solution of $\mathrm{Cr}(\mathrm{III})$ chelate in DMSO showed two weak bands in 400-600 $\mathrm{nm}$ regions, which may be assigning to $\mathrm{A}_{2} \mathrm{~g}^{4} \rightarrow \mathrm{T}_{1} \mathrm{~g}^{4}$ and $\mathrm{A}_{2}^{4} \mathrm{~g} \rightarrow \mathrm{T}^{4}{ }_{1} \mathrm{~g}(\mathrm{~F}) \quad$ transitions ${ }^{(34)}$ respectively suggesting octahedral geometry around $\mathrm{Cr}(\mathrm{III})$ ion. The orange solution of $\mathrm{Ni}(\mathrm{II})$ chelatedisplayed, a well discernable bands at 413 and $455 \mathrm{~nm}$,assignable to $\mathrm{A}_{1} \mathrm{~g}^{1} \rightarrow \mathrm{B}_{1} \mathrm{~g}^{1}$ and $\mathrm{A}^{1}{ }_{1} \mathrm{~g} \rightarrow \mathrm{B}^{1} \mathrm{~g}$ transitions respectively ,then, these are consistent with square planner symmetry around $\mathrm{Ni}^{+2}$ ion ${ }^{(35)}$.

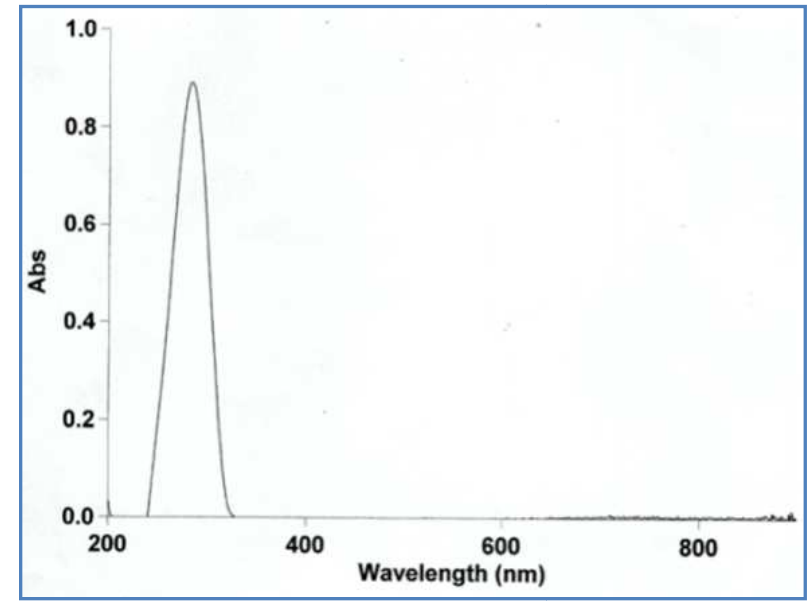

Figure .(5). Electronic spectrum of $8 H Q-p v c$ resin in DMSO Solution.
The white of solution of $\mathrm{Hg}$ (II) chelae showed high intensity bands in 335 and $355 \mathrm{~nm}$ concerning the $\pi-\pi^{*}$ and intra- ligand charge transfer, which agrees well with tetrahedral environment around $\mathrm{Hg}$ (II) ion ${ }^{(34)}$.

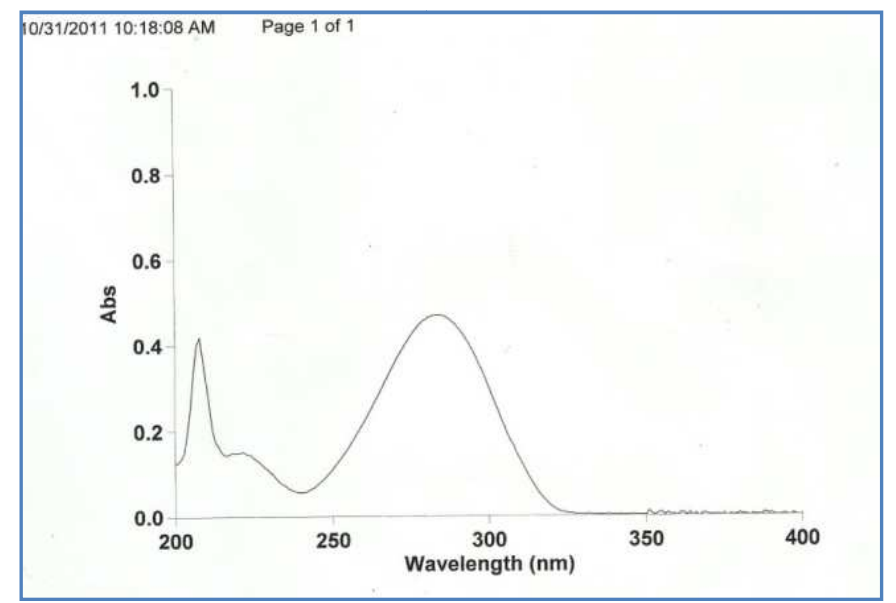

Fig .(6.A). Electronic spectrum of Ni( 8HQ-pvc) in DMSO Solution.

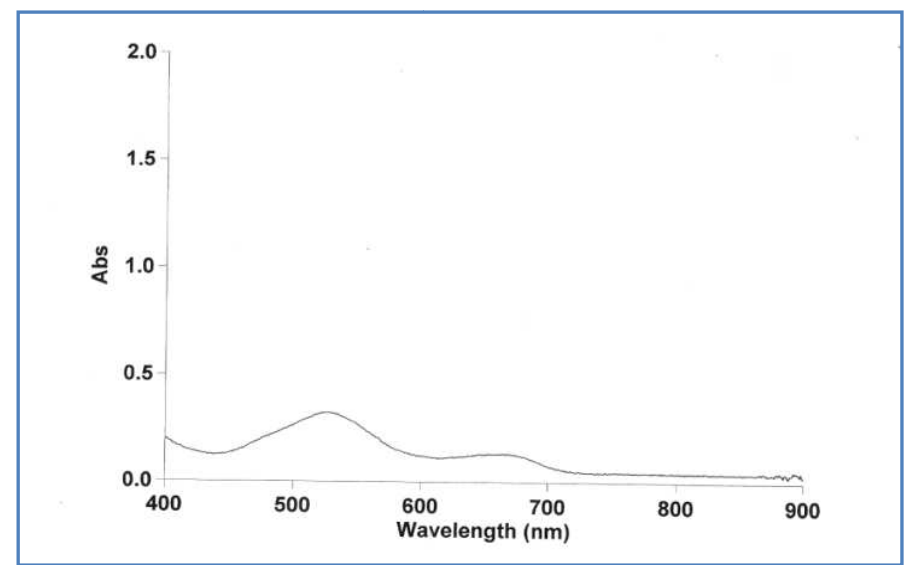

Fig .(6.B). Electronic spectrum of $\mathrm{Ni}(8 H Q-p v c)$ in DMSO Solution 
Table (3). UV-Visible spectra, molar conductance and magnetic moments of polymeric metal complexes

\begin{tabular}{|c|c|c|c|c|c|c|c|}
\hline Compound & $\lambda \mathrm{nm}$ & $\mathrm{cm}^{-1}$ & $\begin{array}{l}\Sigma_{\max } \\
\left(\operatorname{molar}^{-1} \text {. }\right. \\
\left.\mathrm{cm}^{-1}\right) \\
\end{array}$ & Assignment & $\mu_{\text {eff }}($ B.M) & $\begin{array}{l}\text { Proposed } \\
\text { geometry }\end{array}$ & $\mathrm{S} \mathrm{cm}{ }^{2} \cdot \mathrm{mol}^{-1}$ \\
\hline 8H Q-PVC. & $\begin{array}{l}225 \\
336\end{array}$ & $\begin{array}{l}44444 \\
29761\end{array}$ & $\begin{array}{l}23002 \\
30433\end{array}$ & $\begin{array}{l}\pi-\pi^{*} \\
\mathrm{n}-\pi^{*}\end{array}$ & & & 11 \\
\hline $\begin{array}{l}{[\mathrm{CrIII}(8 \mathrm{H}} \\
\left.\mathrm{Q})_{2}\left(\mathrm{H}_{2} \mathrm{O}\right) 3 \mathrm{Cl}\right]\end{array}$ & $\begin{array}{l}250 \\
400 \\
600\end{array}$ & $\begin{array}{l}40000 \\
24213 \\
16666\end{array}$ & $\begin{array}{l}43210 \\
120 \\
90\end{array}$ & $\begin{array}{l}\text { C.T } \\
{ }^{4} \mathrm{~A}_{2} \mathrm{~g}\left(\mathrm{~F} \rightarrow{ }^{4} \mathrm{~T}_{1} \mathrm{~g}(\mathrm{~F})\right. \\
{ }^{4} \mathrm{~A}_{2} \mathrm{~g}(\mathrm{~F}) \rightarrow{ }^{4} \mathrm{~T}_{2} \mathrm{~g}(\mathrm{~F})\end{array}$ & 3.05 & Octahedral & 75 \\
\hline $\mathrm{NiII}(8 \mathrm{H} \mathrm{Q})_{2}\left(\mathrm{H}_{2} \mathrm{O}\right)$ & $\begin{array}{l}554 \\
413\end{array}$ & $\begin{array}{l}25000 \\
24100\end{array}$ & $\begin{array}{l}23000 \\
55\end{array}$ & $\begin{array}{l}{ }^{1} \mathrm{~A}_{1} \mathrm{~g} \rightarrow{ }^{1} \mathrm{~B}_{2} \mathrm{~g} \\
{ }^{1} \mathrm{~A}_{1} \mathrm{~g} \rightarrow{ }^{1} \mathrm{~B}_{2} \mathrm{~g}\end{array}$ & 0.0 & Square planar & 45 \\
\hline $\begin{array}{l}\mathrm{CuII}(8 \mathrm{H} \\
\mathrm{Q})_{2}\left(\mathrm{H}_{2} \mathrm{O}\right)_{2}\end{array}$ & $\begin{array}{l}365 \\
550\end{array}$ & $\begin{array}{l}27390 \\
18181\end{array}$ & $\begin{array}{l}31200 \\
130\end{array}$ & $\begin{array}{l}\text { C.T } \\
{ }^{2} \mathrm{~B}_{1} \mathrm{~g}\left(\mathrm{~F} \rightarrow{ }^{2} \mathrm{~B}_{2} \mathrm{~g}(\mathrm{~F})\right. \\
{ }^{2} \mathrm{~B}_{2} \mathrm{~g}(\mathrm{~F}) \rightarrow{ }^{2} \mathrm{Eg}(\mathrm{F})\end{array}$ & 1.29 & Distorted-Oh & 30 \\
\hline $\begin{array}{l}\mathrm{CdII}(8 \mathrm{H} \\
\mathrm{Q})_{2}\left(\mathrm{H}_{2} \mathrm{O}\right)_{2}\end{array}$ & 304 & 23894 & 18770 & $\begin{array}{l}\text { MLCT. } \\
\text { C.T }\end{array}$ & 0.0 & tetrahedral & 41 \\
\hline $\mathrm{HgII}(8 \mathrm{H} \mathrm{Q})_{2}\left(\mathrm{H}_{2} \mathrm{O}\right)$ & $\begin{array}{l}235 \\
355\end{array}$ & 25974 & 20550 & $\begin{array}{l}\pi-\pi^{*} \\
\text { C.T }\end{array}$ & 0.0 & tetrahedral & 40 \\
\hline $\mathrm{PbII}(8 \mathrm{H} \mathrm{Q})_{2}\left(\mathrm{H}_{2} \mathrm{O}\right)_{2}$ & & & 19870 & C.T & 0.0 & tetrahedral & 32 \\
\hline
\end{tabular}

\subsection{Viscometricstudy}

Isometric measurements were carried out in $N, N$ dimethylform amide solution at $25 \mathrm{C}^{0}$ using a TuanFouss ${ }^{(36)}$,table(4) reduced viscosity versus concentration,(0.5-3.0\%) of 8-HQpvc, $\mathrm{Cu}^{\mathrm{II}}-8-\mathrm{HQpvc}$, $\mathrm{Cr}^{\text {II }}-8-{ }^{\mathrm{I}} \mathrm{HQpvc}$ complexes were plotted for each set of data Figure(7). The intrinsic viscosity ${ }^{\left({ }^{(3)}\right.}$ was determined by the corresponding liner plots. The following equations were used to determine Huggins ${ }^{(37)}$.

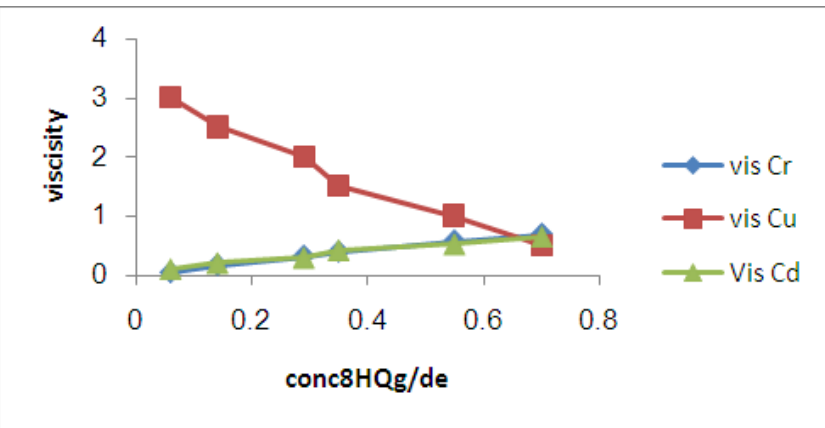

Figure(7). viscometric plot of $\mathrm{Cr}(\mathrm{III}), \mathrm{Cu}$ and $\mathrm{Cd}(\mathrm{II})$ complexes

According to above relation, HQ-PVC, $\mathrm{Cd}^{+2}, \mathrm{Cu}^{+2}$, and $\mathrm{Cr}^{+3} \mathrm{a}$ plot of the via concentration $(\mathrm{g} / \mathrm{dl})$, were liner with slopes of K1 and K2 respectively. Intercepts on the viscosity function axis gave valid in both plots. The calculated values of the constants $\mathrm{k}_{1}$ and $\mathrm{k}_{2}$ for the intrinsic viscosity satisfy the relation $\mathrm{k}_{1}+\mathrm{k}_{2}=0.6$ favorably ${ }^{(36)}$. It was observed that the (8HQ-pvc), Cd (8HQpvc), Cu (8HQpvc) and $\mathrm{Cr}$ (HQ) chelates having showing a higher value of $[\eta]$.

$$
\begin{aligned}
\eta s p / c & =[\eta]+\mathrm{K}_{1}[\eta]^{2} \\
\frac{\ln \eta r o l}{c} & =[\eta]-\mathrm{K}_{2}[\eta]^{2}
\end{aligned}
$$

A according to above relations, a plots of $(\eta s p)-$ and $\frac{\ln \quad \eta r o l}{c}$ agains concertrations of resin 8HQ-p vc and its chelates with $\mathrm{Cr}(\mathrm{III})$ and $\mathrm{Cu}(\mathrm{II})$ were liner with slope $\mathrm{k}_{1}+\mathrm{k}_{2}$, figure $(7)$.

Table (4). isometric plots of $8 H Q p v c, C r(I I I), C u(I I)$ and Cd(II) chelate

\begin{tabular}{llll}
\hline vis $\mathbf{C r}$ & vis $\mathrm{Cu}$ & Vis $\mathbf{C d}$ & con 8HQg/de \\
\hline 0.69 & 0.5 & 0.65 & 0.701 \\
0.58 & 1 & 0.52 & 0.55 \\
0.4 & 1.5 & 0.42 & 0.35 \\
0.33 & 2 & 0.29 & 0.29 \\
0.18 & 2.5 & 0.2 & 0.141 \\
0.058 & 3 & 0.095 & 0.06 \\
\hline
\end{tabular}

\subsection{Distributions Rations of Metal Ions of Different values of PH}

The effect of PH on the amount of metal ions distributed between two phases can be explained by the results given in Figure (8), Table (5). The data obtained from effect of $\mathrm{PH}$ on the removal of metal ions from aqueous solutions indicate that the relative amount of metal taken up by $8-\mathrm{HQpvc}$ resin increases with increasing $\mathrm{PH}$ of the medium ${ }^{(37)}$.

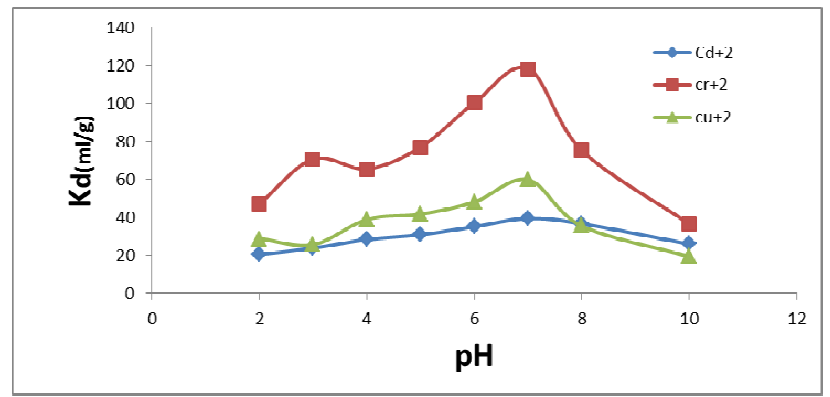

Figure(8). effect of PH on distribution constant of metal ions adsorption

The study was carried out to a definite $\mathrm{PH}$ value for the particular metal ion to prevent hydroxide formation of the 
metal ions at higher $\mathrm{PH}$. In the case of $\mathrm{Cu}(\mathrm{II})$ and $\mathrm{Ni}$ (II) ions, the highest distribution ratio (D) $(390-400)$ of $\mathrm{PH} \simeq 7.0$ whereas the highest value for (D) for $\mathrm{Hg}$ (II) and $\mathrm{Cd}(\mathrm{II})$ at $P H=6.0$. The results of this study help in selecting the optimum $\mathrm{PH}$ for selective uptake of a metal ion from a mixture of different ions ${ }^{(38)}$.The order of distribution ratio of metal ions measured in $\mathrm{PH}$ range 2 to 10 is found to be:

$$
\mathrm{Cr}(\mathrm{III})>\mathrm{Cu}(\mathrm{II})>\mathrm{Cd}(\mathrm{II})
$$

The (8 HQ-PVC) resin is considered as cationic exchange resin, therefore, the exchange may be expressed as:

$$
(\operatorname{Resin}-\mathrm{O})_{\mathrm{H}^{+}}+\mathrm{M}^{+\mathrm{n}} \longrightarrow(\mathrm{Resin}-\mathrm{O})_{\mathrm{M}}
$$

Therefore the tendency of $\mathrm{Cr}^{+3}, \mathrm{Ni}^{+2}, \mathrm{Cu}^{+2}, \mathrm{Cd}^{+2}, \mathrm{Hg}^{+2}$ is much more faster toward increasing the deportation of $-\mathrm{OH}$ phenolic and form strong covalent band of the type chelate.<smiles>C1CON=N1</smiles>

\subsection{Adsorption Isotherms}

The equilibrium experimental data were correlated with Langmuir and Freundlish isotherm models

The studying the adsorption behavior of high concentrations of metal ions, isotherms for the adsorption of $\mathrm{Cr}(\mathrm{III}), \mathrm{Cu}(\mathrm{II})$ and $\mathrm{Cd}(\mathrm{II})$ were obtained by batch method . The isotherms of metal ions can be described by Freundlich equation:-

$$
\log \mathrm{qe}=\log \mathrm{k}+1 / \mathrm{n} \log \mathrm{Ce}
$$

[qe is the amount of metal ion adsorbed per gram of adsorbent (mg. $\left.\mathrm{g}^{-1}\right), \mathrm{Ce}$ is equilibrium the concentration is metal ion solution $\left(\mathrm{mg} . \mathrm{lit}^{-1}\right)$ and the value $\mathrm{n}$ and $\mathrm{K}$ are Freundlich constants $\mathrm{n}$ gives an in dictation of favorability and $\mathrm{k}$ the capacity adsorbent.The liner plot of $\log \mathrm{Ce}$ vs. logqe shows that adsorption follows Freundlich isotherm model. figure(9-10) and table ( 7 ).The Langmuir isotherm is represented by the following equation:

$$
\mathrm{Ce} / \mathrm{qe}=1 / \mathrm{q} \max +\mathrm{Ce} / \mathrm{q} \max
$$

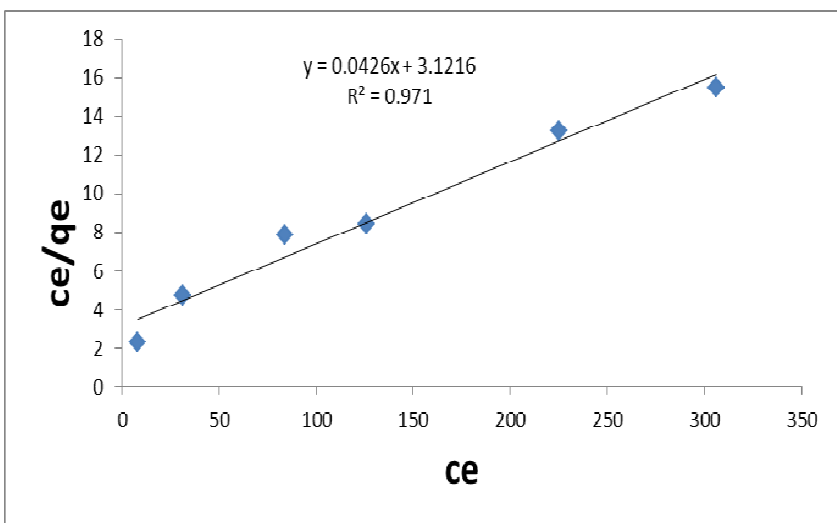

Figure (9). Langmiur adsorption of Cr(III)

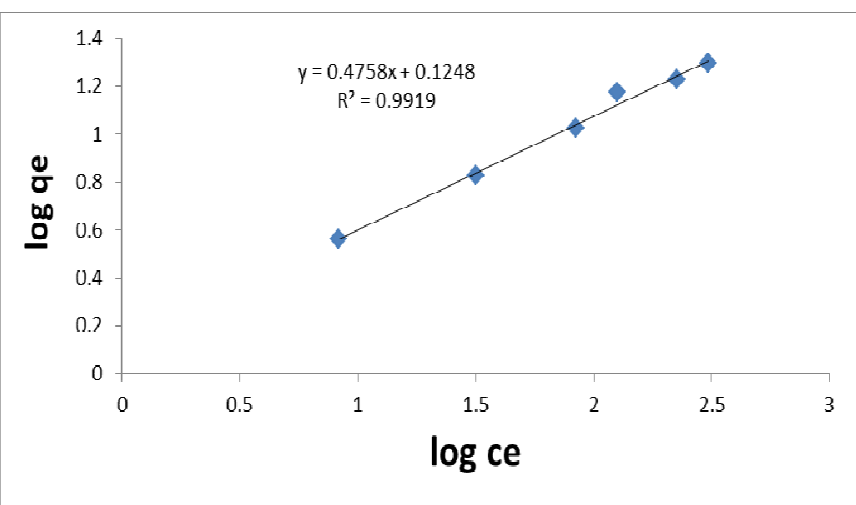

Figure (10). Freundlich adsorption of $\mathrm{Cr}$ (III)

Where $\mathrm{Ce}$ is the equilibrium concentration $(\mathrm{mg} / \mathrm{L})$, qe is the amount adsorbed at equilibrium time $(\mathrm{mg} / \mathrm{L})$, and $\mathrm{q}$ max and $b$ are Langmuir constants related to the adsorption capacity and energy respectively. The plot of Ce /qeverses is liner. This result shows that the adsorption of metal follows Langmuir isotherm model .Figure (11), Table( 5,6 )

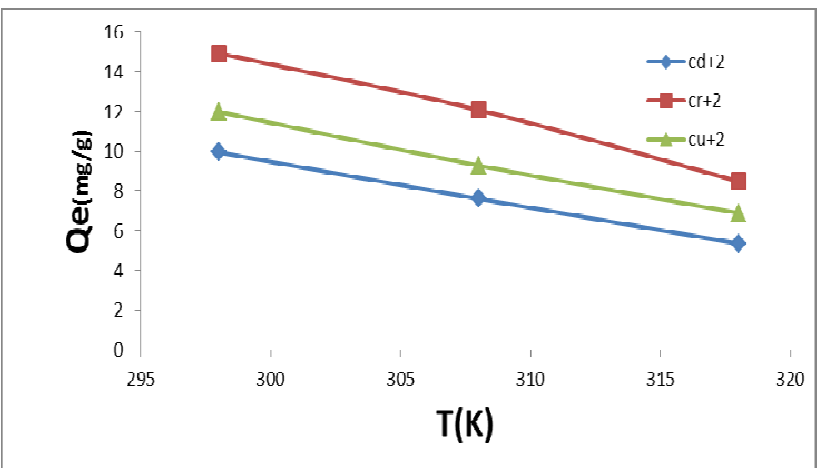

Figure(11). Vant Hoffs plot for adsorption metal ions on P.V.C-8HQ.

Table (5). Distribution ratio $\left(K_{d}\right)$ of different metal ions as function of the $P H$ of $8 H Q-P v c$ resin Distribution ratio of ratio of $M^{+2}$ at different $P H$

\begin{tabular}{llll}
\hline $\mathbf{P H}$ & $\mathbf{K}_{\mathbf{d}} \mathbf{C r}(\mathbf{I I I})$ & $\mathbf{K}_{\mathbf{d}}-\mathbf{C u}(\mathbf{I I})$ & $\mathbf{K}_{\mathbf{d}}-\mathbf{C d}(\mathbf{I I})$ \\
\hline 2 & 47.32 & 29 & 20.63 \\
3 & 70.88 & 25.8 & 23.95 \\
4 & 65.65 & 39.1 & 28.56 \\
5 & 77.09 & 41.9 & 31.01 \\
6 & 100.44 & 48.3 & 35.31 \\
7 & 118.52 & 60 & 39.68 \\
8 & 75.49 & 35.7 & 36.84 \\
\hline
\end{tabular}

Distribution ratio $(\mathrm{kd})$ of different metal ions $\mathrm{M}^{+2}$ at different $\mathrm{PH}$

$$
\mathrm{D}=\frac{\text { Amount of metal ion absorbed. }}{\text { amount of metal ion in the solution }} \times \frac{\text { Volume of solution }(\mathrm{ml})}{\text { Weight of resin gm }}
$$

$\left[\mathrm{Cr}\left(\mathrm{NO}_{3}\right)_{3}\right] .9 \mathrm{H}_{2} \mathrm{O}, \mathrm{Cu}\left(\mathrm{NO}_{3}\right) \cdot 2 \mathrm{H}_{2} \mathrm{O}, \mathrm{Cd}\left(\mathrm{NO}_{3}\right)_{2}, 4 \mathrm{H}_{2} \mathrm{O}$ 
Table (6). Effect of the temperature on the maximum adsorbed quantity for adsorption of the three metals on $8 H Q-P v c$ resin surface

\begin{tabular}{llll}
\hline \multirow{2}{*}{ T (K) } & \multicolumn{3}{l}{ Quantity of Adsorption } \\
& Cr(III) & Cu(II) & Cd(II) \\
\hline 298 & 14.95 & 12 & 9.96 \\
308 & 12.1 & 9.3 & 7.62 \\
318 & 8.5 & 6.9 & 5.37 \\
\hline
\end{tabular}

Table (7). Adsorption values of the three metals ions on $8 H Q-P v c$ resin surface from aqueous solutions

\begin{tabular}{|c|c|c|c|c|c|}
\hline \multirow{8}{*}{$\stackrel{f}{*}$} & $\begin{array}{c}\mathrm{CO} \\
\mathrm{mg} / \mathrm{l}\end{array}$ & $\mathbf{A}$ & $\mathrm{Ce}$ & R\% & Qe(mglg) \\
\hline & 100 & 0.005 & 8.33 & 91.67 & 3.66 \\
\hline & 200 & 0.0190 & 31.66 & 84.17 & 6.73 \\
\hline & 350 & 0.0503 & 83.83 & 76.04 & 10.64 \\
\hline & 500 & 0.0757 & 126.16 & 74.76 & 14.95 \\
\hline & 650 & 0.135 & 225.0 & 65.38 & 17.00 \\
\hline & 800 & 0.1849 & 306.16 & 61.73 & 19.75 \\
\hline & 200 & 0.0063 & 78.75 & 60.62 & 4.85 \\
\hline \multirow{6}{*}{$\stackrel{\sim}{*}$} & 400 & 0.015 & 187.5 & 53.12 & 8.50 \\
\hline & 600 & 0.0201 & 250 & 58.33 & 14.00 \\
\hline & 800 & 0.033 & 412.5 & 48.43 & 15.50 \\
\hline & 1000 & 0.046 & 575 & 42.5 & 17.00 \\
\hline & 1200 & 0.053 & 662.5 & 44.79 & 21.50 \\
\hline & 250 & 0.0112 & 112 & 55.20 & 5.52 \\
\hline \multirow{5}{*}{$\stackrel{\text { T }}{\tilde{T}}$} & 500 & 0.0251 & 251 & 49.80 & 9,86 \\
\hline & 800 & 0.0443 & 443 & 44.62 & 14.28 \\
\hline & 1000 & 0.0595 & 595 & 40,50 & 16.20 \\
\hline & 1200 & 0.0691 & 691 & 42.41 & 20.36 \\
\hline & 1500 & 0.0837 & 837 & 44.2 & 26.52 \\
\hline
\end{tabular}

\subsection{EstimationRate of Metalion Uptake as a Function of Time}

The rate of metal adsorption was determined to find out the shortest period of time within which equilibrium could be achieved as while operating as close to equilibrium condition as possible. As shaking time increases the polymer ( $8 \mathrm{HQ}$ pvc) gets more time for adsorption, hence uptake increases. Figures(9-10), shows that rate of metal non uptake follows the order:

$$
\mathrm{Cr}^{+3}>\mathrm{Cu}^{+2}>\mathrm{Cd}^{+2}
$$

The sequence of rate metal ion uptakeindicates that the rate is directly proportional to size of the metal ion. For example $\mathrm{Cr}^{+3}$ has more change and small size, therefore equilibrium is attained within 90 minutes, while other ions $\mathrm{Ni}^{+2}, \mathrm{Cu}^{+2}$ and $\mathrm{Pb}^{+2}$ have nearly equal cationic size, having same charge, therefore required 120 minute, to attain equilibrium while, $\mathrm{Cd}^{+2}$, and $\mathrm{Hg}^{+2}$ and $\mathrm{Pb}+2$ have large atomic size, therefore requiring 125 minute to attain equilibrium. The trend is in good agreement with earlier workers ${ }^{(35)}$ comparing to soft acids $\mathrm{Pb}^{+2}, \mathrm{Cd}^{+2}$ and $\mathrm{Hg}$ ${ }^{(36)}$ Figure(9).

\subsection{Adsorption Process}

In table(7), we have noticed that the three ions $\left(\mathrm{Cr}^{\mathrm{III}}, \mathrm{Cu}\right.$ and $\mathrm{Cd}^{\mathrm{II}}$ ), the final $\mathrm{pH}$ decreases relatively to initial $\mathrm{pH}$ for different initial concentration used. This corresponds to an increase in the concentration of $\mathrm{H}^{+}$ions in the solution. This phenomena shows that the adsorption of metal ions by the Pvc 8-hydroxyquinoline -5-sulfonic acid surface is made by a process of ion exchange. Indeed, as indicated above the Pvc 8-hydroxyquinoline -5-sulfonic acid surface has a $\mathrm{OH}$ and $\mathrm{SO}_{3} \mathrm{H}$ group which is very reactive with $\mathrm{Cd}(\mathrm{II}), \mathrm{Cu}(\mathrm{II})$ and $\mathrm{Cr}$ (III), to form with them metal Avery stable complexes

A typical adsorption isotherms at given temperature was obtained by plotting qeVsCe for again 8HQ-pvc resin, equation $^{(36)}$.

$$
\mathrm{q}=\left(\frac{\mathrm{C}_{0}^{\prime}-\mathrm{C}^{\prime}}{\mathrm{d}}\right) \mathrm{V}
$$

Where $\mathrm{q}_{\mathrm{e}}=$ the equilibrium metal ionconcentration resin in mole /g

$\mathrm{C}_{0}-\mathrm{C}_{\mathrm{e}}=$ initial and equilibrium concentrations of metal ions under study in mole/lit.

$\mathrm{V}=$ volume of solution in liter , and $\mathrm{d}=$ weight of resin (8HQ- pvc) in $\mathrm{g}$.

The Figures (9-14)clearly indicate that these isotherms are all of the favorable type referred to in literature ${ }^{(38)}$ with increasing values of $\mathrm{Ce}$, the values of qe of reaches the saturation level of the adsorbate on the adsorbent lie, formation of monolayer of the PVC-8HQ bonded with metal ions understudy. This value actually represents the maximum amount of metal ions that thePVC-8HQcould hold under a given set of experimental conditions. In order to verify to what extent the isotherms adhere to Langmuir and Freundlich adsorption isotherm representative plots of $\operatorname{linq}_{\mathrm{e}} \mathrm{VslinC}_{\mathrm{e}}$ for Freundlich (eq.1) and .1/ $\mathrm{q}_{\mathrm{e}} \mathrm{vs} \quad 1 / \mathrm{C}_{\mathrm{e}}$ for Langmuir (equation 3) are accordingly shown in Figures (11).These plots indicate satisfactory adherence to isotherms within the range of concentrations employed in this work.

The high efficiency of PVC-8HQ resin to remove the metal ions especially $\mathrm{Cr}(\mathrm{III}), \mathrm{Ni}(\mathrm{II})$ and $\mathrm{Cu}(\mathrm{II})$, may be attributed to homogeneous distribution of active sites on the resin surface, since the displacement of hydrogen ions of -OH group in position (8), with metal ions understudy and nitrogen $\left(\mathrm{N}_{1}\right)$ of quinolone ring tend to form five membered ring which is kinetically stable ${ }^{(37)}$ and agree with sequins stability of metal complexes Irving Williamson ${ }^{(38)}$.

$$
\mathrm{Cu}^{2+}>\mathrm{Cr}^{3+}>\mathrm{Cd}^{2+}
$$

The maximum amount of metal ion adsorbed by $0.25 \mathrm{gm}$ was calculated by Langmiur and Freundlich models 
(equations 1, 3). The adsorption capacity of modified resin (8HQ-pvc) for metal ions is shown in table (8). As can be seen, the plots of Lagmuir and Freundlich models effective describe the adsorption data with all R2 values more than 0.98 for all ions.

$$
(\% \text { Adsorption })=[(\mathrm{C} 0-\mathrm{Ce}) / \mathrm{C} 0] .100
$$

Where $\mathrm{C}_{0}$ is the initial concentration of metal ion in solution (mg. Lit-1), and Ce is the concentration of metal ion in the filtrate (mg.lit-1).

\subsection{Effect of Temperature on $\mathrm{Cr}$ (III), $\mathrm{Cu}$ (II) and Cd (II) Adsorption by PVC-Resin}

The sorption experiments were repeated at various temperatures in range of $293 \mathrm{~K}, 298 \mathrm{~K}, 308 \mathrm{~K}$ and $318 \mathrm{~K}$, the results are presented in fig(?) and table (1). The amount of $\mathrm{Cr}$ (III) ion adsorbed was $98.9 \%$ at $298 \mathrm{~K}$, whereas at $308 \mathrm{~K}$ it was $70.4 \%$ and at $318 \mathrm{~K}$ the uptake of the metal ion had decreased to $66 \%$.Copper ion uptake by PVC-8HQ, followed a similar pattern of behavior with a sharp increase at $293 \mathrm{~K}(96 \%)$,followed by sharp decrease, the amount of $\mathrm{Cu}$ (II) ion uptake $89 \%$ at $298 \mathrm{~K}$ and $61 \%$ at $318 \mathrm{~K}$. Chromium ion show the same effect, but the uptake of the metal ion had decreased from $99.8 \%$ at $293 \mathrm{~K}$ to $45 \%$ at 318 $\mathrm{K}$ It can be seen that the metal ions uptake follows a similar pattern, but the amount adsorbed at a particular temperature differ. These results indicate that the uptake of metal ions increases at lower temperature. The decrease of the uptake of heavy metal ions with increase in temperature may be due to that insufficient to retain the metal ions and the binding site. This could lead to desorption or cause the metal ions to bounce off the surface of resin instead of combining with it. Therefore, increase in temperature may be associated with decrease in the adsorption.

\subsection{Thermodynamic Parameters of Adsorption}

The effect of temperature on the adsorption extent of the three metal that's chose onPVC-8HQsurface has been studied at three different temperatures (25, 35, 45and $37.5 \mathrm{oC})$. The experimental data and the general shapes of the three metal adsorption are given in table (6) and figure () The results showed an increasing in the adsorption of metal ions on resin PVC 8-hydroxyquinoline -5-sulfonic acid with decreasing temperature, hence the adsorption process appeared to be exothermic ${ }^{(37)}$ and this indicates the entity of absorption process as the adsorbed molecules diffused in the porous of the adsorbent, and increase the rate of the diffusing with decreasing temperature. Likely, the absorption process will be accompanied by the adsorption and get the sorption process (i.e. both the adsorption and the absorption could happen together and this phenomena could be seen clearly from the shape of the isotherms at high temperatures which differs completely in their shapes from the isotherms (25and $35^{\circ} \mathrm{C}$ ) as can be seen in figure (11).

On the other hand, the adsorption of $\mathrm{Cr}(\mathrm{III}), \mathrm{Cu}(\mathrm{II}), \mathrm{Cd}(\mathrm{II})$ on resin PVC-8HQwas decreased with the increasing temperature, as it is shown in table (9) and this is consistent with the thermodynamic properties of adsorption and indicating exothermic process ${ }^{(39)}$. This could be interpreted as a result of weakening of attractive forces between the metal ions and the resinPVC-8HQsurface with the decreasing temperature.

There were no significant differences found in the amount of $\mathrm{Cr}(\mathrm{III}), \mathrm{Cu}(\mathrm{II}), \mathrm{Cd}(\mathrm{II})$ on resin PVC-8HQ surface at the studied range of different temperatures $(25,35,45$ and $37.5^{\circ} \mathrm{C}$ ). ) which indicates that the adsorption process for this $\mathrm{Cr}(\mathrm{III}), \mathrm{Cu}(\mathrm{II}), \mathrm{Cd}(\mathrm{II})$ in this range of temperatures would be temperature independent that means that the quantity adsorbed in the lowest temperature would not be desorbed perceptibly in the highest degree in the studied range of temperatures and the adsorb ate-adsorbent interactive forces are relatively strong.

The equilibrium constant $(\mathrm{K})$ for the adsorption process at each temperature is calculated as in the following equation:-

$$
K=\frac{\text { Qe } \times M}{\text { Ce } x \mathrm{~V}}
$$

Where $\mathrm{Qe}=$ the amount adsorbed in $\mathrm{mg}$ per one gram of adsorbent.

$\mathrm{Ce}=$ the equilibrium concentration of the adsorbate expressed in $\mathrm{mg} / \mathrm{L}$.

$\mathrm{M}=$ the weight of the adsorbent $(\mathrm{g})$

$\mathrm{V}=$ the volume of the metal ions solution used in the adsorption process

The change in free energy $(\Delta \mathrm{G})$ could be determined from the following equation mentioned:-

$\Delta \mathrm{G}=$ - RT InK

Where R: the gas constant (8.314 J. mol-1 deg-1).

$\mathrm{T}$ : the absolute temperature.

The change in enthalpy (the heat of adsorption $(\Delta \mathrm{H})$ may be obtained from the following equation:-

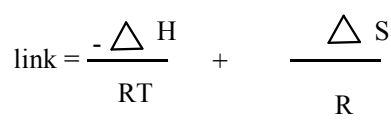

Where $\Delta H=$ enthalpythe maximum uptake of adsorption at a certain value of equilibrium concentration $(\mathrm{Ce})$ that was fixed for all temperature of study.

Table (9) showed values at different temperature. Plotting (In $\mathrm{Xm}$ ) versus $(\mathrm{I} / \mathrm{T})$ should produce a straight line with a slope $=(-\Delta H / R)$ as shown in figure (11).

The change in entropies $(\Delta S)$ was calculated from Gibbs equation

$\Delta \mathrm{G}=\Delta \mathrm{H}-\mathrm{T} \Delta \mathrm{S}$.

\section{Conclusion}

PVC bound to 8-hydroxy-quinolin-5-sulphonic acid has be synthesized by chlorine displacement reaction between PVC and 8-hydroxyquinolin-8-sulphonic acid in presence bof piperidine as catalyst. The polymeric metal complexes 
of newly resin were prepared by direct interaction of PVC-8HQ copolymer and hydrated metal chlorides and nitrates of $\mathrm{Cr}(\mathrm{III}), \mathrm{Ni}(\mathrm{II}), \mathrm{Cu}(\mathrm{II}), \mathrm{Pb}(\mathrm{II})$ and $\mathrm{Cd}(\mathrm{II})$ ions.

We have choiced some highly toxic metal ions for studying the adsorption in aqueous solutions to attain optimum conditions to reach maximum removal of such toxic metal ions from water.The resultant polymer showed high efficiency for metal ions adsorption. The $\mathrm{pH}$, temperature, time and resin content have great influence on the sorption. $\mathrm{Cu}$ (II) and $\mathrm{Ni}$ (II) ions removed at $\mathrm{pH} 8-9$, This could be explained by at low $\mathrm{pH}$, amine groups in the beads easily form protonation that induced an electrostatic repulsion for $\mathrm{Cu}$ (II), $\mathrm{Ni}$ (II) ions. At low $\mathrm{pH}$ of solutions increase $\mathrm{H} 3 \mathrm{O}+$ concentration and intensifies the competition between $\mathrm{H} 3 \mathrm{O}+$ and heavy metal ions for complexion sites. Whereas adsorption for $\mathrm{Cr}$ (III) ions at 7-8 decreased, this is due to the solubility of Cr (III) ions at high ph. Heavy metal ions accumulation from single ion solutions at $\mathrm{pH}$ 8-9 is in order; $\mathrm{Cu}$ (II) $<\mathrm{Ni}$ (II) $<\mathrm{Cr}$ (III). Whereas at low $\mathrm{pH}$ the order will be; $\mathrm{Cr}$ (III) $<\mathrm{Cu}$ (II) $<\mathrm{Ni}$ (II).The decreasing of total adsorption in multi element solutions indicates that a competitive inhibition may occur for Cr (III) by the other cations in the solution, with limited specificity related to ionic radii or tendency for complex formation, depend on $\mathrm{pH}$ of solution.

\section{References}

[1] Amit, B., Rawlins, J.W., Ray, P., Polymer Crafting and Crosslinking. JOHN WILEY \& SONS, INC, (2009).

[2] Agarry, S.E., Owabor, C.N. and Ajani, A.O. Modified Plantain Peel As Cellulose-Based Low-Cost Adsorbent for the Removal of 2,6-Dichlorophenol from Aqueous Solution: Adsorption Isotherms, Kinetic Modeling, and Thermodynamic Studies. Chemical Engineering Communications, (2013), (8), 1121-1147

[3] Biji, B., D.S Kumar, Y. Yasunhida and A.Jayakrishnam, 2005." Chemical modification of poly (vinyl chloride) resin using poly (ethylene glycol) toimprove blood compatibility" Biomaterials", 26: 3495-3502.

[4] Chen, Y., Y. Song, Y. Zhang and Lang. A tricobalt(II) coordination polymer incorporating in situ generated 5-methyltetrazolate ligands. Inorganic Chemistry Communications, 11: PP. 572-575, 2008.

[5] Chereminisoff $P$, and EllerpuschF(1978), Chem Interaction, Hand book, Us. Pp 281-329 D.Feng, C.Aldrich, H.Tan H, MineralsEngineering, (2001) 13, pp.623-642

[6] D.N.Sathyanaryan" Electronic Absorption spectroscopy and Related Techniques '1st. ed. New Delhi (2001).

[7] Dyer J .R" Applications of Absorption spectroscopy of organic compounds prentice $\mathrm{H}$ all of India, 2nd ed ., New Delhi (1971),33.[Kuman K., Chang C.A. and Tweedle, "The investigation of complex stability of complexes using Bjerrum method", Inorg. Chem., Vol.32, p. 587. 1995.

[8] E.M. pratic , J.N. barbe, H.D. Juneja, L.J paliwel, Europ. Polym.J (2007), 43.pp (5000-5010).
[9] Emad Y. Synthesis, spectroscopic studies and fungicidal activity of some dioganotin(IV) with 2[(pheylcarbonyl) amino] propanoato. Journal of King Saud University, 24: PP.167-170, 2012.

[10] F. Vernon „K.N.Nyo,AnolgChem.Act. 93(1977)203. Goswami A, Singh AK, VenKa, 8-Hydroxy quniolineanchored to silica gel via new moderate sizelinkaTalanta 60 B (2003):1141-1154

[11] GurnuleW.B ,paliwalLj.Kharatrj.Ssynthsis. React. Inorg.Met.Org.Chem.(2001):31(8), pp.1453- 1477

[12] Gupta RH, Zade AB, GurnuleW.B,J.UHraSci phys. SCi. (2007);19(3), 359-366. H.FreundlichJournal of physical chemistry,(1906) 57, pp.385-470

[13] H.B. Pancholi, M.M.Patel".J.Polym. 1" Ion -exchange properties of tetra polymers with bivalent Metal ions perform. J.polym (1991), 3, pp. 257-262.

[14] HayaticFilik, MicrochimActa (2002), 140, pp.205-210

[15] K. Nakamato "Infrared and Raman Spectra of Inorganic and coordination compound " Willey Interscience New York(1978).

[16] Langmuir, J. Am. Chem . Soc.(1918), 40, pp. 1361-1403

[17] Ling P.S, Paliwal ;L J and Juneja H.D. Proc. Nat, Acad. Sci. (2001), 71(A), 205

[18] Lutfar M.R, Eur.poly.J.(02000, 36, 2105.

[19] Mhamdi, M., Galai, H., Mnasri, N., Elaloui, E. and Trabelsi-Ayadi, M. (2013), Adsorption of lead onto mectite from aqueous solution. Environmental Science and Pollution Research, 20 (3), 1686-1697.

[20] M.M,Jadho, L.J. Paliwal ,N.S. Bhcve, J.App. polym. Sci., (2005), 109, 1606- 1610

[21] N.Raman , S.R Johnson and A.Sukthicevel, J. coord. Chem.62(2009), 691.

[22] Moulay, S. Chemical modification of poly(vinyl chloride)-Still on the run. Progress in Polymer Science, 35, PP. 303-331, 2010

[23] Patel J.R, Sutariya D.H and Patel M.N, React. Polym. (1995), 25,17

[24] Pahel .J R, Mutariya DH and Patel MN, Rect. Polymer.1995, 25,17

[25] P.a.Dhakite and W.B.Gurnule ,Eurp.J. of chem. 8(3), 2011).pp.1186-1190

[26] R. C. De Geiso, L. G. Donaruma, E.A. Tomicchelatinon ion polymer, Anal . Chem . (1962) 34, pp,. 845- 847)

[27] Raesh, N, J, Appl. Polym,Sci.(2011)108, pp.747-756

[28] R.H. Coupta, A.B.Zade , W.B. Gurnule, J, Appl. Polym,(2008), 109, 3315-3320

[29] R.N.singru ,W.B.Gumule, J. of Thermal Analysisandgalorimety. (2010), 100: 1027-1036.

[30] S.Chandara , S.D. Sharma, Transition Met. Chem. 27 (2002) $] 732$.

[31] S.S. Rahangdale, A.B. Zade, W.B. Gurnule, J. Appl. Polym. 
Sci. 108(2008), pp. 747-756.

[32] S.S. Rahaujclale ,A.B.Zade, W.B.Gurnule (2009), chelation Ion exchange properties of resins , E.J. chem. 6, pp.835-843).Roth, E., Mancier, V. and Fabre, B. (2012), Adsorption of cadmium on different granulometric soil fractions: Influence of organic matter and temperature. Geoderma, 189), 133-143

[33] Sharma, R.K" Design, Synthesis and Application of chelatingpolymers for separation and Determination of trace and toxic metal ion"s (2001), Pure Appl. Chem. 73(1), pp.181-186 V.V Haiwase, A.B.Kalambe, K.M.Khedkar and S.D.Deosarkar, Europ. J. of chem., 7(1), pp.287-290.

[34] X. Liu, H. Chen, Ch. Wang, R. Qu, Ch. Ji, Ch. Sun, Q. Xu, Adsorption properties of amidoximated porous acrylonitrile/methyl acrylate copolymer beads for $\operatorname{Ag}(\mathrm{I})$, Polym.Advan.Technol, 2010, doi:10.1002/pat.1714.
[35] M. Barkat, D. Nibou, S. Chegrouche, A. Mellah, The positive value of $\Delta \mathrm{S}^{\circ}$ reflects the affinity of $\mathrm{Hg}$ (II) for the resins used. Kinetics and thermodynamics studies of chromium(VI) ions adsorption onto activated carbon from aqueous solutions, Chem. Eng. Process. 48 (2009) 38-47.

[36] L. Deng, Y. Su, H. Su, X. Wang, X. Zhu, Sorption and desorption of lead (II) from wastewater by green algae Cladophorafascicularis, J. Hazard. Mater.(2007), 143 pp.220-225.

[37] W.J. Weber Jr., J.C. Morris, Removal of Biologically-Resistant Pollutants from Waste Waters by Sorption. Advances in Water Pollution Research, Pergamon Press, New York, 1962, pp. 231-266.

[38] I. Langmuir, J. Am. Chem. Soc. 40 (1918) 1361.

[39] H.M.F. Freundlich, Z. Phys. Chem. 57 (1906) 385. 